\title{
A soil stratigraphic unit provides evidence for Late Quaternary climate change in the Chobe Enclave, northern Botswana
}

\section{Peter N. Eze ( $\nabla$ ezep@biust.ac.bw )}

Botswana International University of Science and Technology https://orcid.org/0000-0003-4636-2843

Loago N. Molwalefhe

Botswana International University of Science and Technology

Ndiye M. Kebonye

Czech University of Life Sciences Prague: Ceska Zemedelska Univerzita v Praze

\section{Research Article}

Keywords: Middle Kalahari, Soil geochemistry, Palaeohydrology, Clay mineralogy, Palaeosol carbonates

Posted Date: February 16th, 2022

DOI: https://doi.org/10.21203/rs.3.rs-1298832/v1

License: (c) (i) This work is licensed under a Creative Commons Attribution 4.0 International License.

Read Full License 


\section{Abstract}

A quarry in the Chobe Enclave, northern Botswana, exposes a prominent pedostratigraphic unit of approximately 8 metres consisting of two pedostratigraphic levels (PL), older PL1 and younger PL2. In a region where proxies for palaeoenvironmental reconstruction are terribly lacking, this study assessed the potentials of paleosols (fossil soils) to answer fundamental questions about weathering, pedogenic intensity and environmental change using macromorphology, geochemistry and clay mineralogy. $\mathrm{SiO}_{2}$ is the dominant major oxide (40.6- 98.9 wt. \%) followed by $\mathrm{CaO}$ (0.02-29.6 wt. \%), $\mathrm{Fe}_{2} \mathrm{O}_{3}$ (0.48- 2.64 wt. \%), $\mathrm{MgO}(0.14-1.81 \mathrm{wt}$ \% $)$ and $\mathrm{Al}_{2} \mathrm{O}_{3}(0.29-0.93 \mathrm{wt}$. \%). The clay-sized minerals present in the paleosols are sepiolite, quartz, calcite and kaolinite. The carbonates had strong positive correlation with $\mathrm{Sr}\left(R^{2}=\right.$ 0.935), while $\mathrm{Fe}_{2} \mathrm{O}_{3}$ had weak positive correlation with $\mathrm{TiO}_{2}\left(R^{2}=0.0187\right)$. $\mathrm{PL} 1$ developed on materials of fluvial origin and is genetically immature with $\mathrm{A} / \mathrm{C}$ horizons. In comparison with modern soil, PL1 would qualify as Entisols (Fluvent or Fluvaquent in Soil Taxonomy). PL2 is comparable to modern Calsisol and formed from protracted period of post burial dissolution, downward translocation and recrystallization of the palustrine carbonates to form pedogenic carbonates. Calcification, incipient ferralization and leaching of soluble salts are the dominant pedogenic processes in the pedostratigraphic section. Weathering and pedogenesis were generally incipient in the unit. Late Quaternary hydrological dynamics in the Chobe Enclave was the major driver for the formation of the soil stratigraphic unit. This study demonstrates the applicability of paleosols for reconstructing and discerning palaeoenvironmental and climate dynamics and gives the possibility of connecting pedosedimentary processes in the area to regional palaeoenvironmental archives.

\section{Introduction}

Evidence of global and regional climate oscillation during the late Pleistocene-Holocene epochs is well documented (Konecky et al., 2011; Timmermann and Friedrich, 2016). In the semi-arid areas of southern Africa, it is marked by increased frequency of extreme climatic events and hydrological responses (Kusangaya et al., 2014). The Kalahari Basin covers a large expanse of lowland area in Botswana and extends into Namibia, South Africa, Angola, Zambia, and Zimbabwe (Fig. 1). Being a huge basin of internal drainage into which aeolian, fluvial and palustrine sediments have accumulated since the late Cretaceous (Grove, 1969), the middle Kalahari has been a hotspot for paleoenvironmental reconstructions mostly through geological, geomorphological, and lately ecological archives (e.g. Burrough et al., 2007; Cordova et al., 2017). Multiple proxy evidence has confirmed a varying Quaternary history for the middle Kalahari, but climate dynamics in this area is still poorly understood even after five decades of paleoenvironmental research (Burrough et al., 2009).

Chobe Enclave in the middle Kalahari Basin of northern Botswana has been influenced by the Pleistocene-Holocene climate variability (Burrough and Thomas, 2009). The present day Chobe Enclave is under the influence of: (i) the Congo Air Boundary (CAB) and Intertropical Convergence Zone (ITCZ), which are major tropical air mass convergence systems; (ii) three main river systems of the Okavango, 
Kwando-Linyanti, and the Zambezi-Chobe which bring waters from the equatorial Angolan highlands, and (iii) tectonics, given that the local fault system is an extension of the East African Rift Zone (Moore et al., 2012). Therefore, Chobe Enclave owes it geomorphic properties to the complex Quaternary palaeohydrological dynamics influenced by both climate and/or tectonic changes. Most paleoenvironmental reconstruction studies of the middle Kalahari have been focused on the Mababe subBasin (Fig. 1). This study is the first to focus on the potential of alluvial paleosols (fossil soils) from Chobe Enclave to contribute to our knowledge of the paleoenvironments of the middle Kalahari.

Climate parameters, the most active of which are precipitation and temperature, exert strong influence on the nature and properties of soils (Jenny, 1994). Sitting at the interface between the atmosphere, lithosphere, hydrosphere and biosphere, soils and paleosols have the potential to archive the prevalent environmental and climatic conditions under which they formed (Beverly et al., 2018). Globally, paleosols have been successfully used for regional and site-specific palaeoenvironmental reconstruction. Proxies that include particle sizes distribution, macromorphology, geochemistry and clay mineralogy of paleosols and sediments are strong indicators of a combination of pedogenesis, provenance, weathering intensity, hydraulic sorting, abrasion, redox condition and diagenesis (Eze and Meadows, 2014a; Eze et al., 2016a; Huntsman-Mapila et al., 2006). This implies that geochemical and pedogenic proxies are responsive to palaeoenvironmental and paleoclimate changes.

It has been shown that Chobe Enclave has more soil diversity than earlier reported (Romanens et al., 2019). A rare exposure of a deep sand quarry in Chobe Enclave reveals a soil stratigraphic (pedostratigraphic) unit consisting of two levels: a thick unit of paleosol carbonate overlying a genetically immature soil profile developed on alluvial sediments. In a geochronological study, Diaz et al. (2019) reported different phases of active deposition and landscape stability spanning MIS6 to MIS1 during which carbonate islands were formed in the Chobe Enclave. Using geochemical indicators of weathering and pedogenesis, we seek to understand the environmental and climate dynamics, and the pedosedimentary processes at a deep pedostratigraphic section in the Chobe Enclave. In consequence, the objectives of this study are: (i) to characterise the paleosol carbonate of the pedostratigraphic unit using their macromorphological, physico-chemical, geochemical, and clay mineralogical properties; and (ii) to assess weathering and pedogenesis in the unit; and (iii) to reconstruct the environmental conditions of the area. The findings will help us to establish the relationship between pedogenic and geomorphic processes during periods of stability and instability in a semi-arid climate. Trace element compositions are particularly useful as these elements generally remain immobile during the processes of weathering, transport and deposition.

\section{Site Description}

\subsection{Environmental setting}

Chobe Enclave is located in the middle Kalahari Basin (latitudes $19-22^{\circ} \mathrm{S}$ ), northern Botswana. The studied pedostratigraphy lies on longitude $24.308167^{\circ} \mathrm{E}$ and latitude $18.104944^{\circ} \mathrm{S}$ (Fig. 1). The basin is 
characterised by an extensive body of sand of approximately $2.5 \times 10^{6} \mathrm{~km}^{2}$ and this is the parent material on which soils in the area have developed (Jones, 1980). The wet season in area lasts from November to March and is characterised by heavy thunderstorms brought by fluctuations of the Intertropical Convergence Zone (ITCZ). Mean annual rainfall is about $650 \mathrm{~mm}$, making it one of the wettest areas in Botswana (Jones, 2002). The dry season is from April to October and has high temperatures ranging from 30 to $40^{\circ} \mathrm{C}$ in the day. The foremost vegetation in the area includes Colophospermum mopane, Acacia sp., Terminalia sericea or Philenoptera nelsii, with riparian forests along the Linyanti River and isolated dry floodplains and wetlands in the northeast (Romanens et al., 2019).

\section{Methods}

\subsection{Field investigation}

Reconnaissance field surveys resulted in the identification of a pedostratigraphic unit exposed at a sand Quarry site in Chobe Enclave. Macromorphological properties of the soils and paleosols, as well as features related to erosion and sedimentation processes such as soil horizon thickness, type and topography of boundaries and coatings; and all profile designations were done in accordance with the FAO/WRB Guideline for soil profile description (FAO, 2006). Samples were collected from each genetic horizon of the two pedostratigraphic levels (PLs), five samples from PL1 and four from PL2 (Fig. 2).

\subsection{Laboratory analysis}

Pre-treatment of samples involved air drying at room temperature, removal of large roots and gravel and passing through $2 \mathrm{~mm}$ sieve. Particle size distributions of the samples (after the removal of carbonates with dilute $\mathrm{HCl}$ ) were performed on laser granulometry using Malvern Mastersizer 3000 (Worcestershire, UK) connected to a Hydro MV, wet dispersion unit (Malvern, Worcestershire, UK) and the data were analysed using the Mastersizer $3000, \mathrm{v} 1.0 .1$ software. Soil reaction $(\mathrm{pH})$ and electrical conductivity (EC) were measured in a 1:2 soil to solution ratio and the values read off using $\mathrm{pH}$ meter and EC glass electrodes respectively. The carbonate content was determined gasometrically by measuring the volume of carbon dioxide evolved during reaction with hydrochloric acid using an Eijkelkamp calcimeter.

The analysis of the total elemental composition of the samples was carried out in the Minerals-Geochem laboratory of SGS, Randfontein, South Africa. The suite of major rock-forming oxides (reported in \%) was determined by the Borate Fusion Method. A sample weighing $0.7 \mathrm{~g}$ was mixed with lithium tetraborate flux and fused to form a homogenous glass bead. The borate fusion was followed by analysis of the glass bead on the WDXRF Spectrometer. The loss on ignition (LOI) at $1000^{\circ} \mathrm{C}$ was determined separately by gravimetry. The minor and trace elements were determined by sodium peroxide fusion method.

Sample (0.2-2.0 g) was weighed into a crucible containing $\mathrm{NaO}_{2}$ and $\mathrm{NaOH}$. The mixture was then fused. The sample was leached, acidified and made up to volume. The sample was then analysed by ICP-OES. 
To assess elemental redistribution through weathering and pedogenesis, a fundamental approach which entails normalization of all chemical elements of interest by an immobile element (in this study, Ti) as proposed by Brimhall and Dietrich (1987) was applied. Titanium and Zr are good indicators of detrital minerals (Kebonye and Eze, 2019). Under post-depositional palustrine conditions, $\mathrm{Ti}$ and $\mathrm{Zr}$ are chemically immobile (Winchester and Floyd 1977) and have the potential to provide a measure of abundance of some heavy minerals such as Ti oxides before weathering. Changes in provenance are detectable from $\mathrm{Zr}$ /Ti ratios (Reynolds et al. 2001; Reynolds et al., 2004). The rationale behind the use of $\mathrm{Zr} / \mathrm{Ti}$ ratio is that the ratio varies across rock types, e.g., from mafic (e.g., basalt) to more silicic rocks (e.g., rhyodacite). Iron and Ti usually vary together in the soil and sedimentst and their ratio is useful in the evaluation of possible loss of Fe through post-depositional dissolution (Reynolds et al., 2004). Weathering Index of Parker (WIP $\left.=(100)\left[\left(2 \mathrm{Na}_{2} \mathrm{O} / 0.35\right)+(\mathrm{MgO} / 0.9)+\left(2 \mathrm{~K}_{2} \mathrm{O} / 0.25\right)+(\mathrm{CaO} / 0.7)\right]\right)$ proposed by Parker (1970) and Chemical Index of Alteration (CIA $\left.=(100)\left[\mathrm{A}_{2} \mathrm{O}_{3} /\left(\mathrm{A}_{2} \mathrm{O}_{3}+\mathrm{CaO}+\mathrm{Na}_{2} \mathrm{O}+\mathrm{K}_{2} \mathrm{O}\right)\right]\right)$ of Nesbitt and Young (1982) were used to assess the degree of chemical weathering in the samples. WIP has an optimum fresh value of $>100$ and optimum weathered value of 0 while CIA has an optimum fresh value of $\leq 50$ and optimum weathered value of 100 . Both WIP and CIA have long been adjudged good for assessing weathering in silicate rocks (Price and Velbel, 2001). Desilication Index ( $\mathrm{DI}=\mathrm{SiO}_{2} /\left(\mathrm{Fe}_{2} \mathrm{O}_{3}+\right.$ $\mathrm{Al}_{2} \mathrm{O}_{3}+\mathrm{TiO}_{2}$ ), a method that assesses the degree of weathering by comparing mobile silica with resistant oxides (titanium oxide) was also used to assess weathering (Stockmann et al., 2016). The lower the DI value, the more optimal the level of weathering (Fiantis et al., 2017).

\section{Results}

\subsection{Pedostratigraphy}

In accordance with the FAO/WRB guideline of soil profile description, the section qualified as "Bkkm1: Bkkm2: Bkkm3: Bkkm4: ACb: Cb1: Cb2: Cb3: Cb4". The two bottom horizons (Cb3 and Cb4) were wet as a result of underground water capillarity. There are variations in the thickness and morphology of the pedostratigraphic levels at Chobe Enclave: an older genetically immature buried alluvial paleosol (PL1) overlain by a strongly cemented paleosol carbonate (PL2) (Fig. 2). A total of nine distinct genetic horizons were identified after careful observation and delineation of the approximately $8 \mathrm{~m}$ deep pedostratigraphic unit: five horizons in PL1 and four in PL2 (Fig. 2). The horizon boundary between PL1 and PL2 is abrupt.

\subsection{Macromorphology and physico-chemical descriptions}

Some striking variations in morphological, physical and chemical properties typical of depositional environments were observed PL1 and PL2 (Fig. 2). Similar to the horizon depths, the colours of the soils varied remarkably across the PLs. The colours are brown on the surface horizon and faded to light brownish gray in the deepest horizons (Fig. 2). While PL1 had predominantly weak granular to single grained structure, the paleosol carbonates (PL2) were structureless (massive). Cementation by carbonates was principally responsible for the development of massive structure of PL2. There were few 
fine roots in the uppermost horizons of both PL1 (ACb and Ab2) and PL2 (Bkkm1 and Bkkm2) which gradually vanished as one moved down the respective PLs. All horizons of PL2 reacted vigorously to dilute hydrochloric acid indicating the presence of carbonates.

Particle size distribution could not be determined for PL2 due to its cemented massive nature making disaggregation of particle impossible. Fine sand and silt dominate the particle size of PL1 (Table 1). The $\mathrm{pH}$ of the soils and sediments ( $\mathrm{C}$ horizons) ranged from slight to moderately alkaline (7.8-9.7). The electrical conductivity values of PL1 were relatively on the low side ranging from 0 to $80 \mu \mathrm{S} / \mathrm{cm}$. (Table 1). The calcium carbonate contents of the paleosol carbonates (PL2) were high (23.1-43 g kg${ }^{-1}$ ) and nonexistent in PL1 except in ACb possibly due to leaching. The presence of clasts (see arrows in Fig. 3) is indicative of pedogenesis resulting in pedogenic palaeosol carbonate in PL2.

\section{Table 1: Physico-chemical properties of the paleosols}

\begin{tabular}{|c|c|c|c|c|c|c|c|c|c|c|}
\hline Horizon & $\begin{array}{l}\text { Depth } \\
\text { (cm) }\end{array}$ & $\begin{array}{l}\text { coarse sand } \\
500-2000 \mu \mathrm{m}\end{array}$ & $\begin{array}{l}\text { medium sand } \\
250-500 \mu \mathrm{m}\end{array}$ & $\begin{array}{l}\text { fine sand } \\
150-250 \mu \mathrm{m}\end{array}$ & $\begin{array}{l}\text { Silt } \\
63-2 \mu \mathrm{m}\end{array}$ & $\begin{array}{l}\text { Clay } \\
<2 \mu \mathrm{m}\end{array}$ & Texture & $\begin{array}{l}\mathrm{pH} \\
\left(\mathrm{H}_{2} \mathrm{O}\right)\end{array}$ & $\begin{array}{l}\text { EC } \\
(\mu \mathrm{s} / \mathrm{cm})\end{array}$ & $\begin{array}{l}\mathrm{CaCO}_{3} \\
\left(\mathrm{~g} \mathrm{~kg}^{-1}\right)\end{array}$ \\
\hline & & & & & & - & & & & \\
\hline BKkm1 & $0-145$ & nd & nd & nd & nd & nd & nd & nd & nd & 37.3 \\
\hline Bkkm2 & $145-260$ & nd & nd & nd & nd & nd & nd & nd & nd & 43.0 \\
\hline Bkkm3 & $260-450$ & nd & nd & nd & nd & nd & nd & nd & nd & 23.3 \\
\hline Bkkm4 & $450-480$ & nd & nd & nd & nd & nd & nd & nd & nd & 48.7 \\
\hline $\mathrm{ACb}$ & $480-510$ & 18.1 & 162.4 & 702.2 & 116.6 & 0.6 & loamy sand & 9.7 & 200 & 1.5 \\
\hline $\mathrm{Cb} 1$ & $510-550$ & 32.0 & 133.8 & 706.0 & 120.2 & 7.9 & loamy sand & 8.8 & 80 & - \\
\hline $\mathrm{Cb} 2$ & $650-733$ & 10.7 & 174.0 & 710.7 & 96.2 & 8.3 & loamy sand & 8.1 & 0 & - \\
\hline $\mathrm{Cb} 3$ & $733-758$ & 18.7 & 101.9 & 627.5 & 236.8 & 15.1 & loamy sand & 8.7 & 90 & - \\
\hline $\mathrm{Cb} 4$ & $758-794^{+}$ & 54.8 & 49.7 & 687.8 & 90.2 & 7.3 & sand & 7.9 & 0 & - \\
\hline
\end{tabular}

nd : not determined.

\subsection{Geochemistry}

Major elemental oxide composition results presented in Table 2 show $\mathrm{SiO}_{2}$ to be the dominant major oxide (40.6- 98.9 wt. \%) followed by $\mathrm{CaO}$ (0.02-29.6 wt. \%). Other major oxides like $\mathrm{Fe}_{2} \mathrm{O}_{3}$ (0.48- 2.64 wt. $\%), \mathrm{MgO}\left(0.14-1.81\right.$ wt. \%) and $\mathrm{Al}_{2} \mathrm{O}_{3}(0.29-0.93$ wt. \%) were also present in relatively smaller concentration (Table 2). Trace element contents, particularly large ion lithophile elements (LILE) which have a mobile nature and high field strength elements (HFSE) with immobile property were also analysed. LILE including $\mathrm{Rb}(3.2-12.5 \mathrm{ppm})$ and $\mathrm{Ba}(82-1130 \mathrm{ppm})$ and $\mathrm{Sr}(19-385 \mathrm{ppm}$, only in PL2) were comparatively high (Table 3). Other LILE, however, are low in concentrations including Sr in the PL1 only (<10 - 75 ppm), V (<10 - 55 ppm), Cu (<10 ppm), Co (1.6 - 4.5 ppm), and Rb (3.2 - $12.5 p p m)$, whereas 
the latter HFSE shows low concentrations of $\mathrm{Zr}(<0.01-0.01 \mathrm{ppm}), \mathrm{Y}(1.3-11 \mathrm{ppm})$, and $\mathrm{Nb}(2-5 \mathrm{ppm})$ (Table 3).

On the distribution pattern, the elemental distribution showed some trends between the PLs. It is glaring that $\mathrm{Fe}_{2} \mathrm{O}_{3}$ and $\mathrm{SiO}_{2}$ were higher in $\mathrm{PL} 1$ while $\mathrm{CaO}, \mathrm{MgO}$ were outstandingly higher in PL2. However, oxides including $\mathrm{Al}_{2} \mathrm{O}_{3}, \mathrm{Cr}_{2} \mathrm{O}_{3}, \mathrm{~K} 2 \mathrm{O}, \mathrm{MnO}, \mathrm{Na}_{2} \mathrm{O}, \mathrm{P}_{2} \mathrm{O}_{5}$ and $\mathrm{TiO}_{2}$ were relatively uniform across the PLs. A striking spike in $\mathrm{Sr}$, Ni and $\mathrm{S}$ were recorded in PL2 while the rest of the trace elements showed no clear trend in their variations. A couple of geochemical ratios used to evaluate weathering (WIP, DI and CIA) and provenance $(\mathrm{Zr} / \mathrm{Ti})$ showed more variations across PL1 than PL2 which had all the indices relatively more uniformly distributed (Fig. 4). Calcium had a remarkably strong positive correlation with $\mathrm{Sr}$ (Fig. 5a), while $\mathrm{Fe}_{2} \mathrm{O}_{3}$ had a weak positive correlation with $\mathrm{TiO}_{2}$ (Fig. 5b).

Table 2: Major oxide composition (\%) of the PLs

\begin{tabular}{lllllllllllll}
\hline & $\mathrm{Al}_{2} \mathrm{O}_{3}$ & $\mathbf{C a O}$ & $\mathrm{Cr}_{2} \mathrm{O}_{3}$ & $\mathrm{Fe}_{2} \mathbf{O}_{3}$ & $\mathbf{K}_{2} \mathbf{O}$ & $\mathbf{M g O}$ & $\mathbf{M n O}$ & $\mathbf{N a}_{2} \mathbf{O}$ & $\mathbf{P}_{2} \mathbf{O}_{5}$ & $\mathrm{SiO}_{2}$ & $\mathrm{TiO}_{2}$ & $\mathbf{L O I}$ \\
\hline Bkkm1 & 0.39 & 29.6 & $<0.01$ & 0.48 & 0.06 & 1.81 & 0.05 & 0.11 & 0.016 & 40.6 & 0.08 & 25.92 \\
$\mathrm{Bkkm} 2$ & 0.47 & 26.4 & $<0.01$ & 0.67 & 0.07 & 1.56 & 0.05 & 0.17 & 0.013 & 48.5 & 0.11 & 22.48 \\
$\mathrm{Bkkm3}$ & 0.49 & 27.6 & $<0.01$ & 1.02 & 0.08 & 1.77 & 0.23 & 0.17 & 0.014 & 45.4 & 0.11 & 23.41 \\
$\mathrm{Bkkm} 4$ & 0.55 & 12.5 & $<0.01$ & 1.60 & 0.09 & 0.74 & 0.05 & 0.15 & 0.011 & 73.2 & 0.12 & 11.14 \\
$\mathrm{ACb}$ & 0.61 & 0.33 & $<0.01$ & 2.64 & 0.12 & 0.67 & 0.03 & 0.18 & 0.01 & 93.6 & 0.14 & 2.12 \\
$\mathrm{Cb} 1$ & 0.33 & 0.15 & $<0.01$ & 0.61 & 0.05 & 0.16 & 0.01 & 0.12 & $<0.01$ & 98.9 & 0.14 & 0.53 \\
$\mathrm{Cb} 2$ & 0.58 & 0.29 & $<0.01$ & 2.53 & 0.13 & 0.61 & 0.03 & 0.13 & 0.013 & 94.0 & 0.15 & 2.26 \\
$\mathrm{Cb} 3$ & 0.74 & 0.11 & 0.02 & 0.94 & 0.08 & 0.2 & 0.01 & 0.14 & $<0.01$ & 96.6 & 0.19 & 1.13 \\
$\mathrm{Cb} 4$ & 0.29 & 0.02 & 0.07 & 0.96 & 0.05 & 0.14 & 0.01 & 0.11 & $<0.01$ & 97.3 & 0.14 & 0.05 \\
\hline
\end{tabular}

LOI - Loss on Ignition in a furnace at $950^{\circ} \mathrm{C}\left(=\right.$ chemically bound $\mathrm{H}_{2} \mathrm{O}$ and $\left.\mathrm{CO}_{2}\right)$

$\mathrm{Fe}_{2} \mathrm{O}_{3}$ is expressed as total $\mathrm{Fe}$

Table 3: Trace elements composition (ppm) of the PLs 


\begin{tabular}{|c|c|c|c|c|c|c|c|c|c|c|c|c|c|c|c|c|c|c|c|}
\hline Horizon & $\mathrm{n} \mathrm{Ba}$ & $\mathrm{Cr}$ & $\mathrm{Cu}$ & $\mathrm{S}$ & $\mathrm{Sr}$ & V & $\mathrm{Zn}$ & Co & & Mo & $\mathrm{Nb}$ & $\mathrm{Ni}$ & $\mathrm{Pb}$ & $\mathrm{Rb}$ & $\mathrm{Sc}$ & Th & $\mathrm{U}$ & $Y$ & $\mathrm{Zr}$ \\
\hline Bkkm1 & 934 & 153 & $<10$ & 933 & 370 & 18 & 42 & 3.8 & $<1$ & 10 & 3 & 36 & 18 & 6.0 & $<5$ & 0.6 & 2.50 & 1.3 & $<0.01$ \\
\hline Bkkm2 & 305 & 321 & $<10$ & 899 & 253 & 23 & 10 & 3.8 & $<1$ & 19 & 4 & 34 & 10 & 6.6 & $<5$ & 0.6 & 1.54 & 1.6 & $<0.01$ \\
\hline Bkkm3 & 465 & 14 & $<10$ & 725 & 385 & $<10$ & $<10$ & 4.2 & $<1$ & 2 & 3 & 33 & 9 & 8.6 & $<5$ & 0.7 & 1.33 & 2.1 & $<0.01$ \\
\hline Bkkm4 & 384 & 23 & $<10$ & 383 & 129 & $<10$ & $<10$ & 2.8 & $<1$ & $<2$ & 2 & 18 & 7 & 8.1 & $<5$ & 0.9 & 0.72 & 11.0 & 0.01 \\
\hline $\mathrm{ACb}$ & 795 & 18 & $<10$ & 289 & 19 & $<10$ & 23 & 2.9 & $<1$ & $<2$ & 3 & 7 & 10 & 10.4 & $<5$ & 1 & 0.98 & 5.6 & $<0.01$ \\
\hline Cb1 & 117 & 14 & $<10$ & 194 & 35 & $<10$ & $<10$ & 1.6 & $<1$ & $<2$ & 2 & 7 & 11 & 3.8 & $<5$ & 0.6 & 2.00 & 1.5 & $<0.01$ \\
\hline $\mathrm{Cb} 2$ & 1130 & 15 & $<10$ & 372 & 75 & $<10$ & $<10$ & 3.3 & $<1$ & $<2$ & 3 & 9 & 9 & 11.3 & $<5$ & 0.9 & 2.06 & 10.9 & $<0.01$ \\
\hline $\mathrm{Cb} 3$ & 225 & 460 & $<10$ & 189 & $<10$ & 44 & $<10$ & 2.5 & $<1$ & 29 & 4 & 12 & 10 & 5.0 & $<5$ & 0.9 & 2.75 & 2.5 & 0.01 \\
\hline $\mathrm{Cb} 4$ & 82 & 880 & $<10$ & 142 & 35 & 55 & $<10$ & 2.6 & $<1$ & 54 & 5 & 17 & 8 & 3.2 & $<5$ & 0.6 & 2.19 & 1.8 & 0.01 \\
\hline
\end{tabular}

\subsection{Clay mineralogy}

The mineralogy of the clay-sized particles of the paleosols is shown in Table 4. The minerals present include sepiolite, quartz, calcite and kaolinite. While PL1 had a predominance of quartz and calcite only in Ab1, PL2 had abundance of calcite, quartz and sepiolite.

Table 4: Mineralogy of the clay-sized particles of the paleosols

\begin{tabular}{lllll}
\hline Horizon & Quartz & Calcite & Sepiolite & Kaolinite \\
\hline $\mathrm{Bkkm} 1$ & + & ++ & & \\
$\mathrm{Bkkm} 2$ & + & ++ & + & \\
$\mathrm{Bkkm3}$ & + & ++ & & \\
$\mathrm{Bkkm} 4$ & + & +++ & + & \\
$\mathrm{ACb}$ & +++ & + & & \\
$\mathrm{Cb} 1$ & +++ & & & \\
$\mathrm{Cb} 2$ & +++ & & \\
$\mathrm{Cb} 3$ & +++ & & \\
$\mathrm{Cb} 4$ & +++ & & \\
\hline
\end{tabular}

\section{Discussion}




\subsection{Sedimentation and pedogenesis in the Chobe Enclave from the macromorphological perspective}

The studied soil stratigraphic unit in the Chobe Enclave qualifies as a truncated compound paleosol in an alluvial depositional environment. Although the surface mineral horizon (A) developed on Kalahari sands has been removed by erosion leaving an exposure of hardly cemented $B$ horizon outcrop on the surface (Fig. 2) at the studied unit, the surrounding areas still have their A horizon intact. Carbonate accumulation in the soils of arid and semiarid environments form the basis for their classification as Calsisols in modern soil (e.g. Romanens et al., 2019). However, for cemented horizons of carbonates that are beyond 5 meters in depth should not be seen as part of a modern solum. As obtains in PL2, such massive carbonate horizons rather is an indication of pedogenesis that spanned over hundreds of thousands of years and should be described as relict paleosols (Soil Survey Staff, 2017). There is evidence of pedogenesis in the obliterated structure of the initial palustrine rock from which the palaeosol carbonate developed including illuvial accumulation of carbonates, clasts immersed in the matrix (Fig. 3), brittleness, and very powdery stains of carbonates on the fingers. PL1 on the other hand is a weakly developed buried pedosediments of alluvial sediments origin. According to Romanens et al. (2019), soil formation in the Chobe enclave is strongly driven by complex interactions of vectors including alluvial depositional processes, paleoenvironmental factors such as old alluvial deposits, ancient wind-blown sand deposits, and hydrological dynamics. ).

The horizon boundary between PL1 and PL2 is abrupt. The abrupt boundary between PL1 and PL2 could be explained by divergence in soil development pathways. A critical observation of the soil stratigraphic unit shows that events principally connected with hydrological changes in the region triggered the formation of two morphologically distinct pedostratigraphic levels (PL1 and PL2) as shown from the distinct boundary. Environmental and climate conditions which ensured the geomorphic stability of the landscape at the time PL1 formed was followed by a prolonged period of carbonate-rich sediment deposition, dissolution and translocation of carbonates and hiatus of dry period that led to the hardening of the paleosol carbonate (PL2). Palustrine carbonates deposited between MIS6 to MIS1 dots Chobe Enclave as carbonate islands (Diaz et. al., 2019). The horizonation of PL2 together with the abundant presence of clasts (Fig. 3) provides evidence to support pedogenesis through secondary recrystallization of carbonate out of solution which if often triggered by loss water or dryness.

Granulometric results of PL1 (Table 2) confirms that the parent materials are of alluvial origin and were deposited under low energy given the dominantly fine nature of the particle sizes, well sorted, and leptokurtic to very leptokurtic kurtosis (statistically means that more particle sizes in the distribution tails and more particle sizes close to the mean (i.e. particle size distribution of the samples sharply peaked with heavy tails) with weak textural maturity. These attributes are typical of low energy fluvial or tidal sediment deposits (Blott and Pye, 2001).

\subsection{Geochemical indication of provenance, weathering and pedogenesis}


The parent material (alluvial sediments) in the Chobe Enclave consist of quartz, rock fragments (conglomerates and sandstones) and ferromagnesian minerals from the network of rivers south of the Okavango Alluvial fan (Diaz et al., 2019; Romanens et al., 2019).

A major pedogenic process in the Chobe Enclave includes chemical weathering of the detrital minerals in the alluvial sediments and mobilisation, loss or precipitation of relatively soluble minerals. Geochemical indicators of carbonate precipitation, $\mathrm{Ca} / \mathrm{Ti}$, and iron oxide redistribution, $\mathrm{Fe} / \mathrm{Ti}$ show that calcification and oxidation of iron oxide were the dominant pedogenic processes that shaped the diagnostic horizons of PL2 and PL1 respectively. As expected, the dominantly single grained structure of PL1 enhanced higher rate of soluble salt (e.g. $\mathrm{Na}$ ) leaching than $\mathrm{PL} 2$. The strong $\mathrm{Sr}$ and carbonates correlation $\left(R^{2}=\right.$ 0.935) at Chobe Enclave (Fig. 5a) implies absence of Sr dissolution and mobility. As obtains elsewhere, this is due to the high $\mathrm{pH}$ and $\mathrm{CO}_{2}$ concentration in PL2. On the other hand, the weak positive correlation of $\mathrm{Fe}_{2} \mathrm{O}_{3}$ versus TiO plot points to weak dissolution and mobility of $\mathrm{Fe}$ in the PLs (Reynolds et al., 2004) and of Sr tend to precipitate as authigenic carbonate under high soil pH (Kabata-Pendias 2001). Calcification, a pedogenic processes observed in PL2 are moderate-term pedogenic features and is known to happen in $10^{3}$ years (Targulian and Krasilnikov, 2007).

The stagnic nature of $\mathrm{Cb} 3$ and $\mathrm{Cb} 4$ horizons points to frequent groundwater table rising through capillarity in the fine grained sediments ( $\mathrm{Cb} 3$ and $\mathrm{Cb} 4)$. Since the $\mathrm{C}$ horizons of the stratigraphic unit did not react with dilute $\mathrm{HCl}$, it is most likely that their high $\mathrm{pH}$ could be attributed to alkaline underground water..

\subsection{Palaeoenvironmental inferences}

The Chobe Enclave depositional environment is part of the bigger Kalahari Basin. Pedostratigraphic results of the studied section reveals two paleosol units (PL1 and PL2) believed to have formed as a result of late Quaternary hydrological fluctuations in the area (Diaz et al., 2019). Paleosols are archives of environmental and climate conditions at the time of their formation and have been successfully used for palaeoenvironmental and paleoclimate reconstruction (Eze and Meadows, 2015; Tabor and Myers, 2015a; Eze et al., 2016a). In comparison to modern soils, the studied section is representation of Entisols (PL1) overlain by Calcisols (PL2). Adoption of a universal nomenclature for palaeosols has been a controversial topic in palaeopedology and Quaternary geology because of changes in paleosol properties resulting from post burial alteration (Imbellone 2011; Eze et al., 2016b). Based on the prominent pedogenic classification scheme of paleosols (Mack et al., 1993), PL1 qualify as Protosols because of its characteristic loamy texture and the presence of cambic horizons, while PL2 is Calcisols because of the carbonate enrichment.

Although the studied section is bare at the surface due to local erosion, the immediate surrounding is presently covered by Arenosols developed on white sands of localised sandveld. (Romanens et al., 2019). Calcisols contains significant amount of precipitated secondary carbonates caused by evaporation under arid and semi-arid climates (FAO, 2001). The PL2 horizons are engulfed by secondary carbonates and are physically root restrictive. Modern Calcisols are rare in Chobe Enclave (Romanens et al., 2019) and where 
available contain non-pedogenic (palustrine carbonate) as reported by (Diaz et al., 2019). Our study shows that pedogenic carbonates are present in PL2. According to Soil Survey Staff (2017), carbonates that precipitated in place from soil solution and translocated within the soil profile is considered pedogenic. Since PL2 developed on alluvial quartz rich clastic materials which are non-calcareous parent material, the rate of carbonate accumulation would depend on the rate of at which the $\mathrm{CaCO}_{3}$ originally present in palustrine carbonate can be dissolved and translocated via leaching waters in a soil profile, and inputs from dust and/or rainfall (Gocke et al., 2012).

Based on the law of superimposition, PL1 is clearly older than PL2 and is comparable in attributes to present day Entisols. They correlate as fluvents in USDA Soil Taxonomy. PL1 has buried weakly developed surface horizons and formed on palustrine deposits. The horizons of PL1 are genetically immature which is also supported by the DI, WIP and CIA results (Fig. 4). Brownish colouration by downward translocation iron oxide formed the basis for $\mathrm{A} / \mathrm{C}$ horizon differentiation. Imprints of hydrological activities are evident in the stagnic $\mathrm{Cb} 3$ and $\mathrm{Cb} 4$ horizons at the depth of about 8 meters. Entisols occur over a wide range of climates across the globe. Entisols were among the modern soils delineated in Chobe Enclave by Romanens et al (2019).

The mobility and redistribution of major and trace elements within the soil environments are often influenced by the prevailing environmental and climate conditions affecting weathering .The higher $\mathbf{S r}$ values observed in PL2 implies dryness and precipitation of calcium and magnesium carbonates under arid climate (Küçükuysal and Kapur, 2014), whereas higher values signify more exposure of PL1 to moisture. In a regional context, the morphological and pedostratigraphy of the PL2 depict long term patterns in climate and/or basin settling prompted by strong regional palaeohydrology that gave rise to the Mababe Depression, Makgakgadi Pan and Lake Ngami of the middle Kalahari Basin (Burrough et al., 2009). The differences in geochemical weathering and pedogenic ratios between the paleosol resulted from alternating wet and dry climate cycle in the Chobe Enclave. The development and maturity of PL1 was disturbed by a period of geomorphic instability that produced PL2 (Fig. 2). Periods of geomorphic instability has been reported to precede the development of duplex soils (Eze and Meadows, 2014a). PL1 of the Chobe Enclave are therefore exposed to more humid environments than today. The uppermost horizons of PL2 have been lost and this indicates strong erosion in the Enclave.

The presence of sepiolite in PL2 indicates alkaline soil conditions and high aluminium activity in solution in arid to semi-arid paleoclimate. The dry palaeoenvironmental condition of PL2 is further supported by the calcite, a carbonate mineral which forms from direct precipitation of calcium-rich solution and grows bigger as the waters dry out (Eze and Meadows, 2014b; Tabor and Myers, 2015). The clay-sized minerals are possibly of allogenic (detrital) origin (with higher chances of the little amount of clays present being transported into Chobe Enclave from surrounding catchments.

\section{Conclusions}


This study focused on geochemical indicators of weathering and pedogenesis in a prominent pedostratigraphic unit from Chobe Enclave, NW Botswana. At the depth of about 8 meters, a prominent soil stratigraphic unit shows two distinct pedostratigraphic levels consisting of a weakly developed soilsediment beds and an overlying paleosol carbonate (PL1 and PL2). In comparison with modern soils, PL1 would qualify as Entisols (Fluvent or Fluvaquent in USDA Soil Taxonomy). This implies that going deep in time, the intermittent changes in the hydrological regimes of Chobe Enclave has been a strong driver of soil formation and landscape evolution. From the geochemical indicators, the study area has experienced only incipient chemical weathering and pedogenesis. Calcification, leaching of soluble cations and downward migration of iron oxides are the operating pedogenic processes established from this study. It also implies that that prior to the dry period (MIS 6 to MIS1) under which carbonate paleosols (carbonate island) formed, Chobe Enclave witnessed period of geomorphic stability and wet conditions. Post burial dissolution, translocation and recrystallization of palustrine carbonates commonly found in the Chobe Enclave has culminated in the formation of pedogenic carbonates as found in the unit. From the viewpoint of palaeopedology, this study provides evidence of late Quaternary environmental and climate change in the Chobe Enclave. To improve this study, a high resolution dating of the genetic horizons of PL1 is recommended as the available geochronology of the area only accounted for PL2.

\section{Declarations}

\section{Conflict of interest:}

The authors have no conflicts of interest to declare that are relevant to the content of this article.

\section{Funding:}

This study was jointly funded by Palaeontological Scientific Trust (Grant P00037) and Botswana International University of Science and Technology, Palapye (Grant R00011)

\section{References}

1. Beverly EJ, Lukens WE, Stinchcomb GE (2018) Paleopedology as a Tool for Reconstructing Paleoenvironments and Paleoecology. In: Croft DA, Su DF, Simpson SW (Eds) Methods in Paleoecology. Springer Cham. pp 151-183.

2. Blott SJ, Pye K (2001) GRADSTAT: A grain size distribution and statistics package for the analysis of unconsolidated sediments. Earth Surfaces Processes and Landforms 26: 1237-1248.

3. Brimhall GH, Dietrich WE (1987) Constitutive mass balance relations between chemical composition, volume, density, porosity, and strain in metasomatic hydrochemical systems: results on weathering and pedogenesis. Geochimica et Cosmochimica Acta, 51(3): 567-587.

4. Burrough SL, Thomas DS, Singarayer JS (2009) Late Quaternary hydrological dynamics in the Middle Kalahari: forcing and feedbacks. Earth-Science Reviews 96: 313-326. 
5. Croudace IW, Rothwell RG (2015). Micro-XRF studies of sediment cores: Applications of a nondestructive tool for the environmental sciences, (Vol. 17). Dordrecht: Springer.

6. Das SS, Rai AK, Akaram V, Verma D, Pandey AC, Dutta K, Prasad GR (2013) Paleoenvironmental significance of clay mineral assemblages in the southeastern Arabian Sea during last $30 \mathrm{kyr}$. Journal of Earth System Science, 122: 173-185.

7. Diaz N, Armitage SJ, Verrecchia EP, Herman F (2019) OSL dating of a carbonate island in the Chobe Enclave, NW Botswana. Quaternary Geochronology 49: 172-176.

8. Díez EG, Corella JP, Adatte T, Thevenon F, Loizeau JL (2017) High-resolution reconstruction of the 20th century history of trace metals, major elements, and organic matter in sediments in a contaminated area of Lake Geneva, Switzerland. Applied Geochemistry, 78: 1-11.

9. Eze PN, Knight, J, Evans M (2016a) Tracing recent environmental changes and pedogenesis using geochemistry and micromorphology of alluvial soils, Sabie-Sand River Basin, South Africa. Geomorphology 268: 312-321.

10. Eze PN, Udeigwe TK, Umeugochukwu OP (2016b) Paleosol nomenclature and classification for South Africa: A new perspective. Geoderma Regional 7(3): 323-329.

11. Eze PN, Meadows ME (2015) Geochemistry and paleoclimatic reconstruction of a paleosol sequence at Langebaanweg, South Africa. Quaternary International 376: 75-83.

12. Eze PN, Meadows ME (2014a). Texture contrast profile with stone layer in the Cape Peninsula, South Africa: Autochthony and polygenesis. CATENA 118: 103-114.

13. Eze PN, Meadows ME (2014b) Mineralogy and micromorphology of a late Neogene paleosol sequence at Langebaanweg, South Africa: inference of paleoclimates. Paleogeography, Paleoclimatology, Paleoecology 409: 205-216.

14. Fiantis D, Malone B, Pallasser R, Van Ranst E, Minasny B (2017) Geochemical fingerprinting of volcanic soils used for wetland rice in West Sumatra, Indonesia. Geoderma Regional 10: 48-63.

15. Food and Agricultural Organisation (FAO) (2006) Guideline for Soil Description. 4th ed. FAO, Rome, Italy (109 pp).

16. Food and Agricultural Organisation (FAO) (2001) Lecture Notes on Major Soils of the World. World Soil Resources Report, (9) 334 pp.

17. Gocke M, Pustovoytov K, Kuzyakov Y (2012) Pedogenic carbonate formation: Recrystallization versus migration - Process rates and periods assessed by ${ }^{14} \mathrm{C}$ labeling. Global Biogeochemical Cycles, 26(1). GB1018.

18. Huntsman-Mapila P, Ringrose S, Mackay AW, Downey WS, Modisi M, Coetzee SH, Tiercelin JJ, Kampunzu AB, Vanderpost C (2006) Use of the geochemical and biological sedimentary record in establishing paleo-environments and climate change in the Lake Ngami basin, NW Botswana. Quaternary International 148: 51-64.

19. Imbellone PA (2011) Classification of paleosols. Geociencias 30 (1): 5-13. 
20. Jenny H (1994) Factors of soil formation: A system of quantitative pedology. Chelmsford, MA: Courier Corporation. 191 pp.

21. Jones B (2002) Chobe enclave, Botswana - lessons learnt from a CBNRM project 1993-2002. Gaborone: IUCN/SNV CBNRM Support Programme.

22. Jones CR (1980) The geology of the Kalahari. Botswana Notes and Records, 12:1-14.

23. Kabata-Pendias A, Pendias H (2001) Trace elements in soils and plants CRC Press Inc. Boca Raton, FL, USA.

24. Kebonye NM, Eze PN (2019) Zirconium as a suitable reference element for estimating potentially toxic element enrichment in treated wastewater discharge vicinity. Environmental Monitoring and Assessment, 191(11):1-5.

25. Kücüküysal C, Kapur S (2014) Mineralogical, geochemical and micromorphological evaluation of the Plio-Quaternary paleosols and calcretes from Karahamzall, Ankara (Central Turkey). Geologica Carpathica 65:241-253.

26. Mack G, James W, Monger H (1993) Classification of paleosols. Geological Society of America Bulletin 105: 129-136.

27. Moore AE, Cotterill FP, Eckardt FD (2012) The evolution and ages of Makgadikgadi palaeo-lakes: consilient evidence from Kalahari drainage evolution south-central Africa. South African Journal of Geology. 115(3):385-413.

28. Parker A (1970) An index of weathering for silicate rocks. Geological Magazine 107: 501 -504.

29. Peinerud EK (2000) Interpretation of Si concentrations in lake sediments: three case studies. Environmental Geology, 40(1-2): 64-72.

30. Retallack GJ (1997) Paleosols in the upper narrabeen group of New South Wales as evidence of early triassic paleoenvironments without modern analogues. Australian Journal of Earth Science, 44: 185-201.

31. Reynolds RL, Rosenbaum JG, Rapp J, Kerwin MW, Bradbury JP, Colman S, Adam D (2004) Record of late Pleistocene glaciation and deglaciation in the southern Cascade Range. I. Petrological evidence from palustrine sediment in Upper Klamath Lake, southern Oregon. Journal of Paleolimnology, 31(2): 217-233.

32. Reynolds RL, Belnap J, Reheis MC (2001) Aeolian dust in Colorado Plateau soils: Nutrient inputs and recent change in source. Proc. Natl. Acad. Sci. USA 98: 7123-7127.

33. Romanens R, Pellacani F, Mainga A, Fynn R, Vittoz P, Verrecchia EP (2019) Soil diversity and major soil processes in the Kalahari basin, Botswana. Geoderma Regional 19, e00236.

34. Soil Science Division Staff (2017) Soil survey manual. USDA handbook 18: 120-131.

35. Stockmann U, Cattle SR, Minasny B, McBratney AB (2016) Utilizing portable X-ray fluorescence spectrometry for in-field investigation of pedogenesis. CATENA, 139: 220-231.

36. Tabor NJ, Myers TS (2015) Paleosols as indicators of paleoenvironment and paleoclimate. Annual Review of Earth and Planetary Sciences 43: 333-361. 
37. Winchester JA, Floyd PA (1976) Geochemical magma type discrimination: application to altered and metamorphosed basic igneous rocks. Earth and Planetary Science Letters, 28(3): 459-469.

\section{Figures}

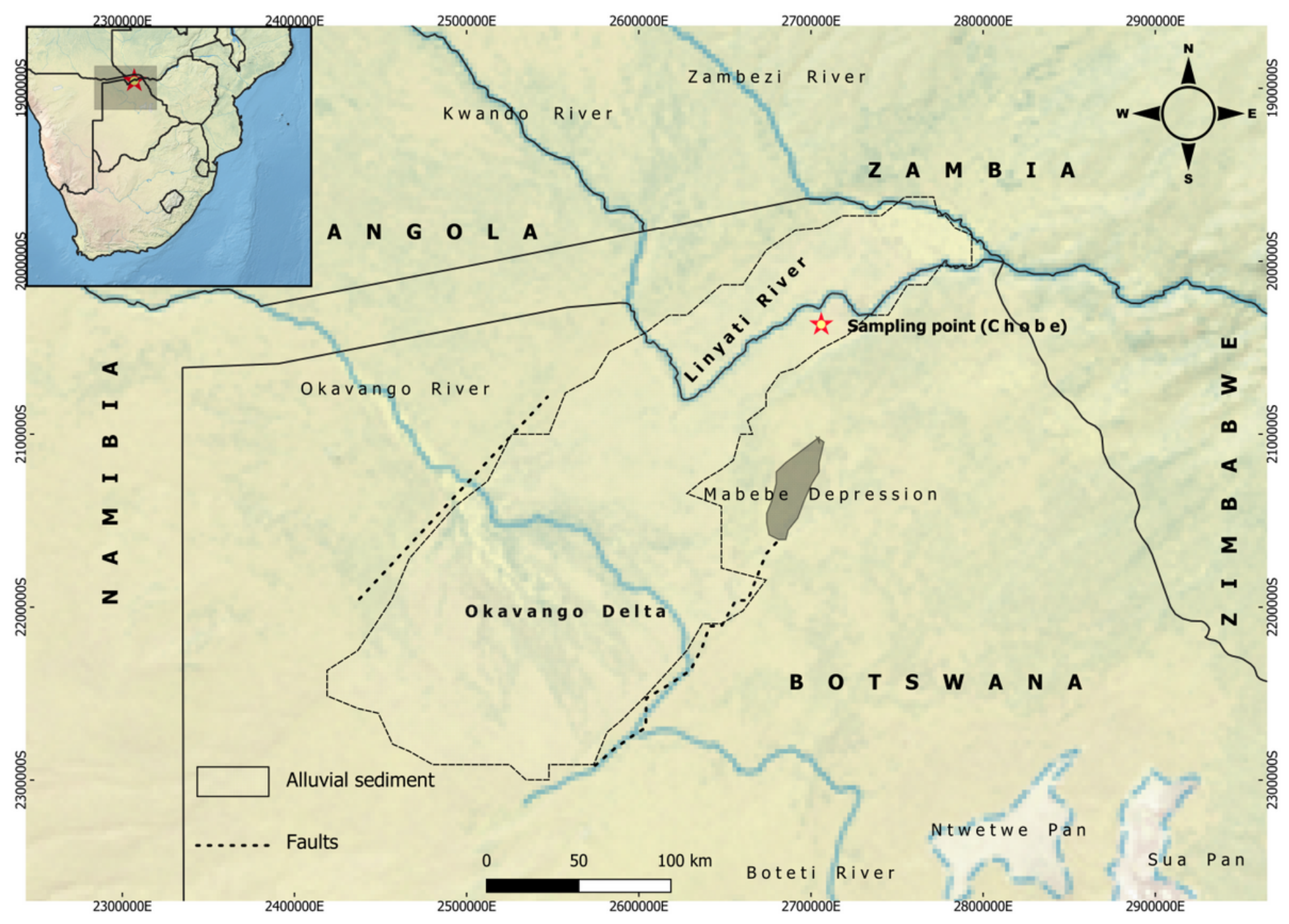

Figure 1

Location map of the study area showing the sampled soil stratigraphic unit. 


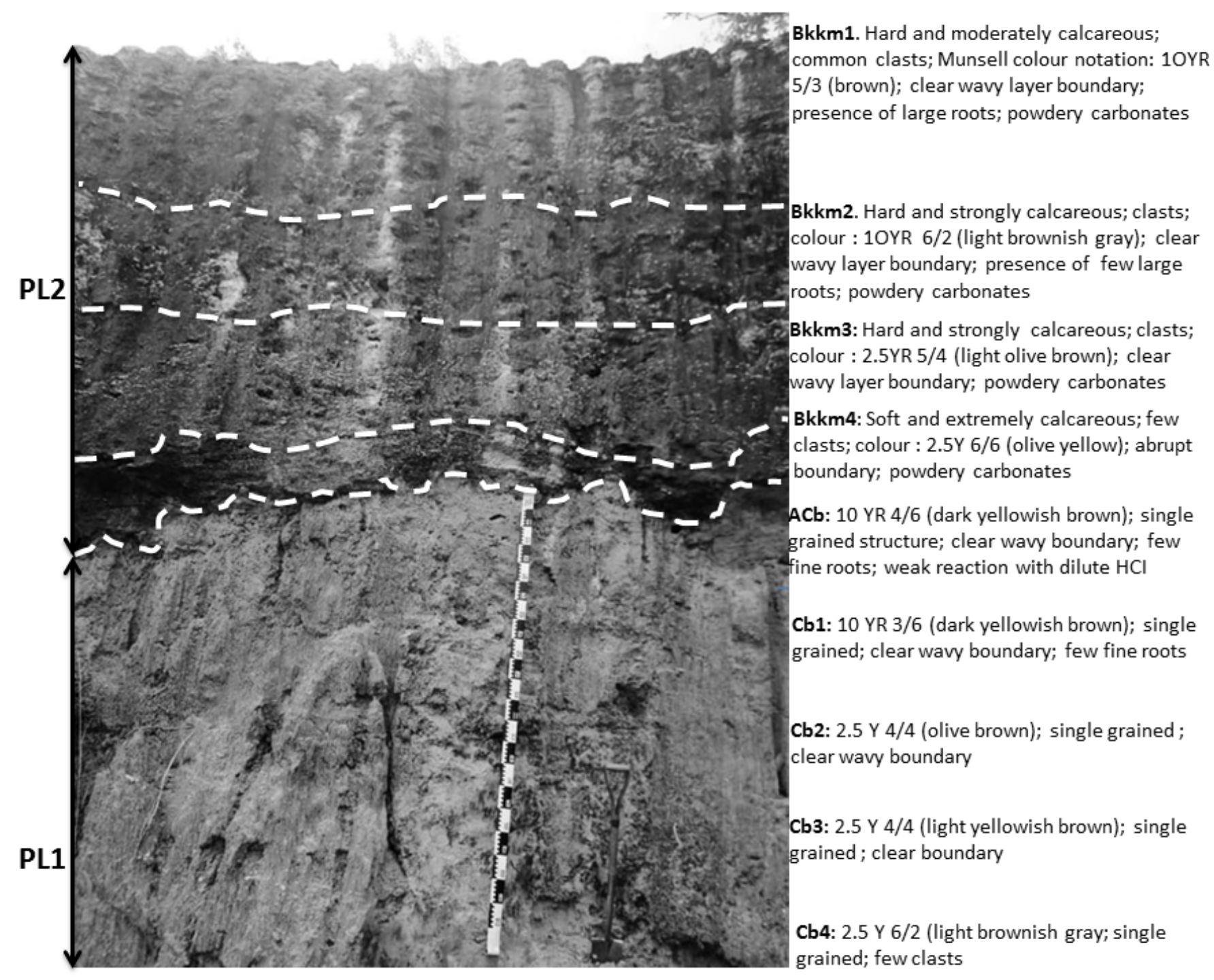

\section{Figure 2}

Schematic representation of the pedostratigraphy unit in the Chobe Enclave. 


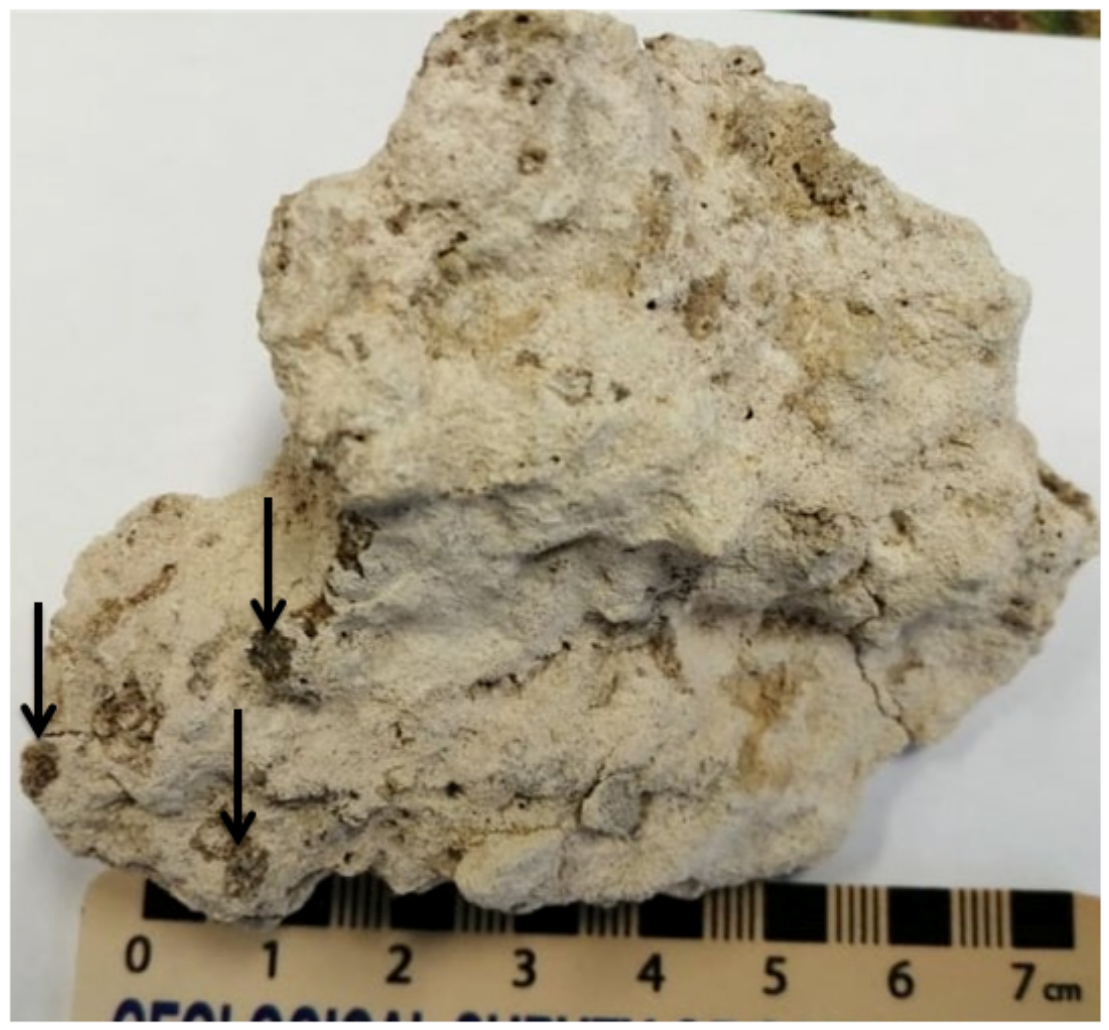

Figure 3

Hand sample of the palaeosol carbonates (PL2). 

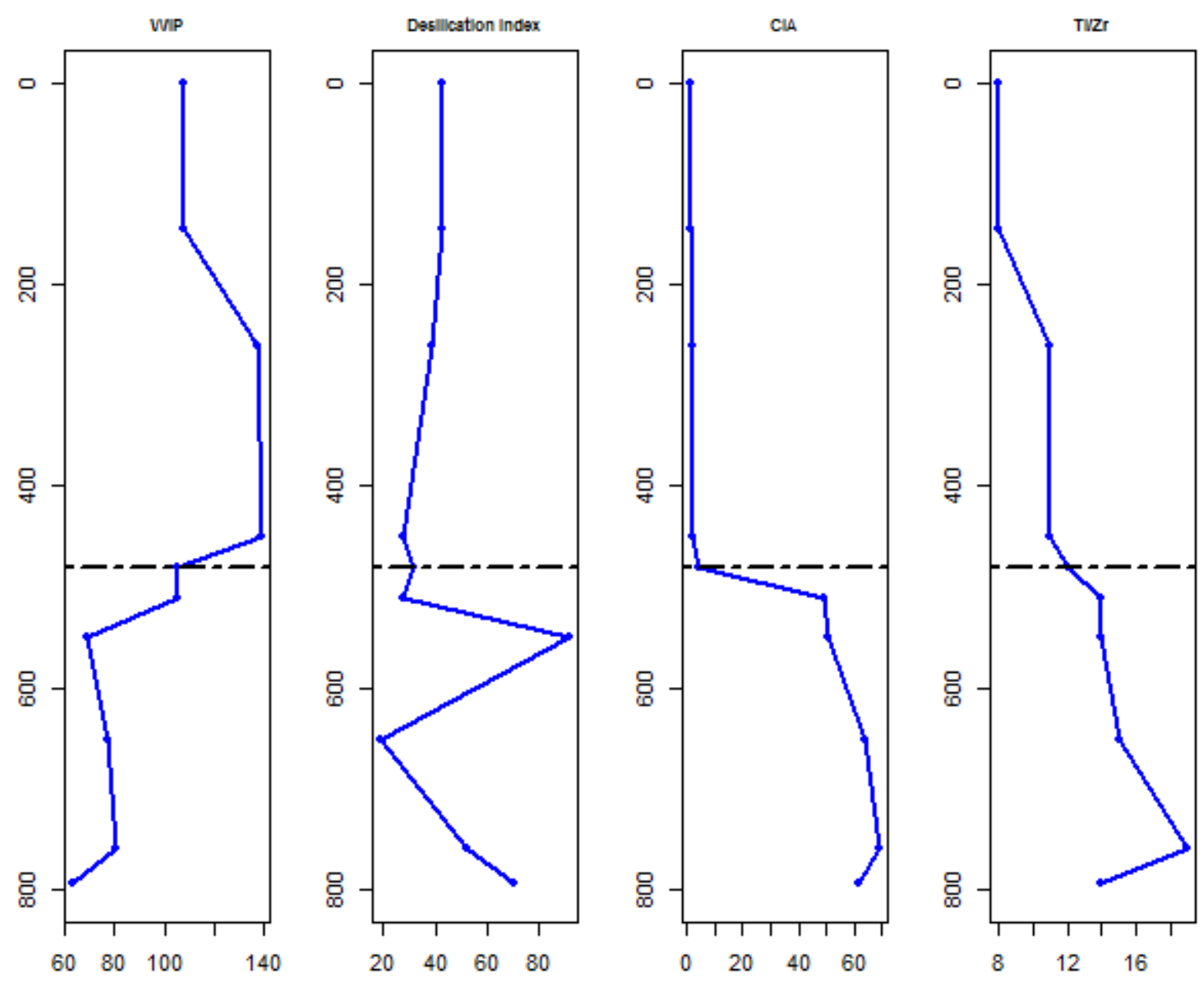

Figure 4

Plots of weathering and pedogenic ratios 


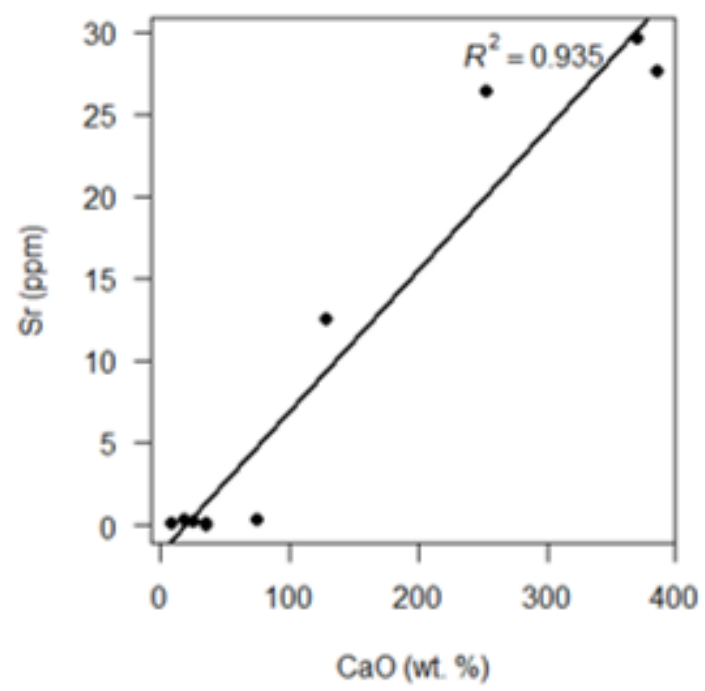

(a)

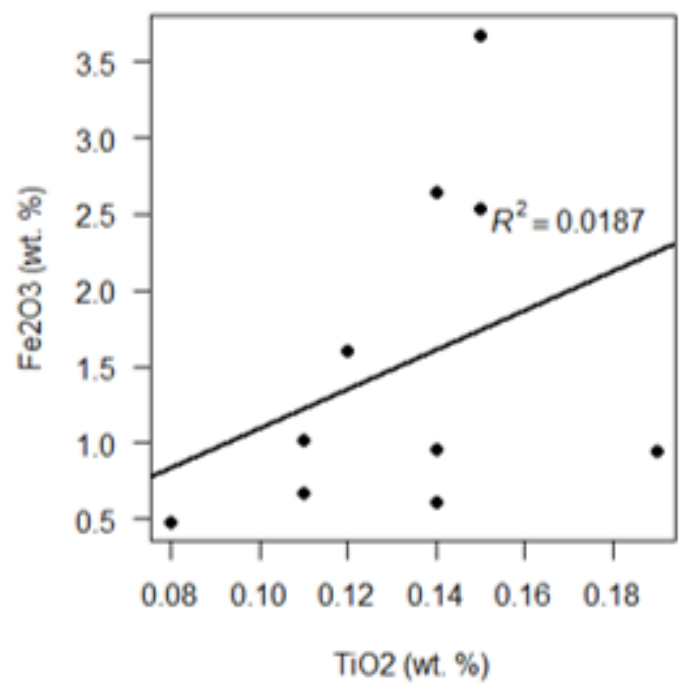

(b)

Figure 5

Bivariate plot of (a) Calcium against $\mathrm{Sr}$ (regression line fit, $R^{2}=0.935$ ), (b) Titanium oxide against iron oxide (regression line fit, $R^{2}=0.0187$ ) 